\title{
Effectiveness and Desirability of Private Higher Education in Nigeria
}

\author{
Oseni, Michael \\ Department of Accountancy, The Polytechnic, Ibadan, Nigeria \\ osenimike@gmail.com
}

\section{Doi:10.5901/jesr.2015.v5n1p151}

\begin{abstract}
The influx of the establishment of private higher educational institutions in Nigeria since the inception of the present democratic dispensation in 1999 is unprecedented. Their effectiveness compared to public institutions is the focus of this paper. Content analysis method was used in this study and the focus was on private universities. Most of these private institutions were established purely for business motives as costs are beyond many Nigerians. The shortcomings in respect of dearth of qualified personnel and infrastructural facilities are more pronounced in these institutions. The unusual interferences of proprietors were common in academic affairs and academic freedom is nonexistent. The fear of the public in respect of acceptability and performance of the outputs to the challenges of graduate unemployment is being allayed by the outstanding performances of some of these graduates in open competitive labour markets. The regulatory and supervisory organs for universities should properly monitor these institutions in order not to turn them to either glorified secondary schools or intellectual prison yards. These private institutions should concentrate on courses that can address the challenges of the time as the liberalisation of higher education will go a long way to ameliorate the social welfare of the citizens like what is being witnessed in the telecommunication industry.
\end{abstract}

Keywords: Higher education, Accreditation, Proprietor, entrepreneurial programmes, National Universities Commission, Private

\section{Introduction}

Formal education started in today's modern Nigeria in the $15^{\text {th }}$ century when the Portuguese merchants in the coastal areas interacted with the natives in their commercial activities. It was reported that international diplomatic relationship was in existence between Oba Esigie of Benin and Portugal during the peak of his reign between 1504 and 1550 and by that time the Oba could read and write Portuguese fluently (Adeuyan, 2011). Benin princes and nobles traveled to Portugal to acquire education during this time. However, 1842 which marked the beginning of Christian missionary activities in Nigeria made significant and far reaching impact in the country as far as formal education was concerned. Thus, formal education brought by the missionaries was interwoven with Christian evangelism. It was after the Christian missionaries got to Badagry that the first formal primary school was established in 1845 . They came first with the bible and later introduced the formal western education to make their work easier. They were interested mainly with the three Rs of education which were reading, writing and the arithmetic. This, ostensibly, would enable the newly converts read the bible, translate the sermon to vernacular and become a catechist of some sort in the vineyard.

The northern part of the country had earlier contact with Islam compared to the southern part. With this religion, Islamic education which is part of worship became widespread among the adherents particularly the political leaders. That was why it was possible for the rulers in the north eastern part of the country to exchange correspondences with the proponents of the jihad affirming that the jihad being prosecuted then was political and not religious.

Education being offered as earlier mentioned was primarily to allow the converts to be able to read the bible and to translate it into the local vernacular. But later, these crops of educated Africans were able to become public letter writers, court clerks and clerical clerks in private and public sectors. It was when openings for higher responsibilities were made available to Africans that higher education was required. It was also these Christian missionaries that were in the forefront of providing secondary education to Nigerians. The Church Missionary Society established CMS Grammar School which was the first secondary educational institution in Nigeria 1859. Other missionary schools were opened in other parts of Nigeria to complement the efforts of the CMS. These schools were named after the names of the towns where they were sited. That was the era of Abeokuta Grammar School, Ibadan Grammar School and ljebu Ode Grammar School which were founded between 1908 and 1913 in the south western part of the country. In the eastern part, Hope Waddell Training Institute Calabar was established in 1895. The first secondary school in northern Nigeria was Katsina College (now Barewa College) which was established in 1921. 
The opportunities for secondary education were not limited to members of these Christian congregations as students of different faiths were given the same opportunities. As the openings were limited, only few were given offers to pursue their secondary education. Government and communities later waded into ownership and running of secondary school education. Most government secondary school institutions were heavily subsidized while communities charged fees for their services. Later, private secondary education was inevitable when these schools were not enough in number to cater for the teeming prospective students produced by, for example, the free education policy in western region.

Nigeria established its first higher institution in 1934 with the opening of Yaba Higher College. Primarily, it was established to provide the much needed middle level manpower requirement for the civil service. Courses in engineering, pharmacy and surveying were offered with the option of finishing the higher degree in Britain which normally would be at first degree level. It also provided training for secondary school teachers, mainly science teachers. As the college offered limited diplomas, those who wanted higher education either had to go abroad for full time study or earn external degrees through correspondence courses. Later, the need to have full university training led to the establishment of University College of Ibadan which was affiliated to University of London in 1948. In 1960, the first full-fledged indigenous and first autonomous university in Nigeria which was founded in 1955 started operation as University of Nigeria, Nsukka. This was closely followed by Ahmadu Bello University, University of Lagos and University of Ife in 1962. Various colleges of Arts and Science were established to prepare students for these Universities.

The need for middle level manpower in the early 1970s led to the establishment of the polytechnics and colleges of technology where various courses from accountancy to engineering were offered. These institutions were fully financed by the owners who were either state or federal governments.

Admission to these universities was through individual examinations conducted by these institutions. But as from 1978, there was a unified system of examination through a common clearing system known as Joint Admission and Matriculation Board. As more secondary schools were established, this institution was offering fewer places for students in the universities. This then resulted in having backlog of students seeking for admission which later prompted demand for private higher education.

Government relaxation on establishment of universities and inadequacy of admission openings to prospective students seem to open the way for establishment of private universities in Nigeria. As missionaries played important roles in the establishment of primary and secondary education in Nigeria, they were not left behind when private establishment of higher institutions started in Nigeria. Churches, mostly, Pentecostals, were in the forefront. But this time around, members were asked to donate their widow's mites for the establishment of their 'university' as benefits that would accrue to their wards and children would be immeasurable. But some of these private universities like Babcock University had been operating in Nigeria as far back as 1959 as affiliates of foreign-based universities.

Private individuals who could satisfy the requirements for the establishment of private universities also established their own universities. Fees were charged, professionals were recruited and infrastructures were put in place. The difference between the fees charged by these private and public universities are in most cases not the same. In private universities, there seem to be free flow of academic calendar without students' unrest or staff union activities which may result to closing of institutions thereby elongating the period of learning.

The inadequacy of these private and public universities had led some prospective students to neighbouring countries, mostly Ghana, to seek the golden fleece thereby resulting in Nigeria's additional external expenditure of N160 billion annually .

With the establishment of these private universities, are they better equipped compared to public universities? Are the fees charged reasonable enough? Are the students being given the value for the fees being charged? Would the products of these private universities be able to compete with the products of public universities? What are the qualities of staff being recruited at these private universities compared to the public universities? What are the long term effects of these private universities on educational system in the country? These issues will be the focus of this paper. The rest of the paper is hereafter divided into four sections. Section two is on conceptual framework and literature review while section three is on research methodology. Findings and discussions are in section four. Section five is on summary, conclusion and recommendation. 


\section{Conceptual Framework and Literature Review}

\subsection{Conceptual Framework}

\subsubsection{Higher education}

Higher education is the next level of education after secondary education. Secondary education is provided after the primary education which is compulsory and universal. The higher education system in Nigeria is composed of universities, polytechnics, colleges of technology, colleges of education, professional and specialized institutions that are affiliates of foreign and local universities. The university system can further be classified as federal, state and private. It can further be categorized as first, second or third generation universities. The Federal government is the owner of all Federal universities while state universities have state governments as the proprietors. The first generation universities are the six universities established prior to mid 1970s (i.e. Ibadan, Nsukka, Ahmadu Bello, Lagos, Ife and Benin). The second generations are those established in the mid 1970s while the third generations are those established in the 1980s and 1990s which include universities of Agriculture and Technology. The new generation universities can be classified as those established since the inception of the democratic dispensation in 1999.

Higher education is different from further education. Further education involves getting additional training or education that will equip an individual to perform better in his chosen career. It may also involve getting additional qualification to be able to attend university education.

\subsubsection{National Universities Commission}

The regulatory agency for university education system in Nigeria is the National Universities Commission which was established in 1962 as an advisory agency in the Cabinet Office. Presently, it is a parastatal under the Federal Ministry of Education (FME). The functions of the commission are succinctly stated in the National Universities Commission Act Cap N81 Laws of the Federation of Nigeria 2004 as follows:

- To advise the President and State Governors, through the Minister, on the creation of new universities and other degree-awarding institutions in Nigeria;

- To prepare, after consultation with the State Governments, the universities, the national manpower Board and such other bodies as it considers appropriate, periodic master plans for the balanced and co-coordinated development of all universities in Nigeria;

- To lay down minimum academic standards in the Federal Republic of Nigeria and to accredit their degrees and other academic awards;

- To ensure that quality is maintained within the academic programmes of the Nigerian University System;

- To make such other investigations relating to higher education as the Commission may consider necessary in the national interest;

- To inquire into and advise the Federal Government on the financial needs, both recurrent and capital, of university education in Nigeria and, in particular, to investigate and study the financial needs of university research and to ensure that adequate provision is made for this in the universities;

- To take into account, in advising the Federal and State Governments on university finances, such grants as may be made to the Universities by the Federal and State Governments, private proprietors and by persons and institutions in and outside Nigeria;

- To undertake periodic reviews of the terms and conditions of service of personnel engaged in the universities and to make recommendations thereon to the Federal Government where appropriate;

- To recommend to the Visitor of a university that a visitation be made to such university as and when it considers it necessary;

- To act as the agency for channeling all external aid to the universities in Nigeria;

- To receive block grants from the Federal Government and allocate them to Federal Universities in accordance with such formula as may be laid down by the National Council of Ministers.

The responsibility of providing guidelines and processing of applications for the establishment of private universities rest with the commission. 


\subsubsection{Joint Admission Matriculation Board (JAMB)}

The board is the clearing house for those seeking admission into tertiary institutions. It started conducting examination in 1978 for university candidates. Hitherto, each university admitted its students by conducting its own concessional examination. Later all polytechnics and colleges of education were brought into the fold with separate examinations which were different from that of university candidates. It was in 2009 that the examinations were harmonized for all candidates seeking admission to tertiary institutions with Unified Tertiary Matriculation Examination (UTME) where a candidate had the option of two universities, two polytechnics and two colleges of education as his or her choice of institutions. As from 2014, a new system was introduced which allow an applicant to a choice of one University, one Polytechnic, one College of Education and one Computer Institute.

\subsection{Literature review}

Compared to other countries in Africa, private higher education in Nigeria had little or no development between 1966 and 1999. The military governments during these periods concentrated their efforts to the unification of the country more than any other social services. Obasi (2007) is of the opinion that with the emergence of the democratic rule in 1999, private higher education which was at its infancy compared to other countries in Africa sprouted after the liberalization of the sector. He concluded that the inability of public universities to cope with increasing demands for admission; inability of the governments to fund expansion; the concomitant falling standards in public universities; frequent closures and unstable academic calendar due to staff and students' unrest were the internal forces that created the demand for private universities while the external driving forces are rooted in the neo-liberal economic policies, information and communication technology (ICT) revolution and globalization. As Ajadi (2010) pointed out, the market-friendly reforms initiated under the Structural Adjustment Programmes (SAP), the deregulation policies and the financial crisis of the states created an encouraging environment for the emergence of the private universities in Nigeria. Before 1999, public universities had a near monopoly in providing university education.

In his studies of private higher education in six African countries, Thaver (2008) observed that the trend in educational curriculum has seriously shifted from the traditional to what the modern world is in need of. Private higher education is positively contributing to social functions in Africa. Courses being offered are now suggesting alignment with the economic and social needs of a modern society. Nevertheless, all countries under studies are constrained by the over-reliance on a cohort of part-time staff. He concluded that academic staffs of private universities were tied mainly to public and private institutions. This practice of moonlighting not only undermines institutional loyalty but places intellectual and resource limits on the extent to which they are able to develop and innovate around curricula.

Government efforts in developing education were manifest during the colonial period and immediately after the independence. Many of the public higher institutions were established during these periods. The downturn in education in Nigeria, according to Uche (2012), could be traced to the incursion of the military into government barely six years after independence in 1966. Next was the civil war that engulfed the newly independent nation just twenty months after the military putsch. He further observed that the introduction of Structural Adjustment Programme (SAP) finally brought education financing to its knees.

This incursion of military into government in Nigeria which had devastating effect was comparable to what happened in Ethiopia when a socialist military coup overthrew the monarchy of Emperor Haile Selassie in 1974 and established an oppressive regime known as the 'Derg' (i.e. committee). This led to government intervention in university affairs, including security surveillance, repression of dissent, mandated courses on Marxism, prohibition of student organisations, appointment of senior university officers and control of academic promotions (Saint, 2004).

The assumption in developing economy is that it is the state that must be responsible for the education of the citizens from the primary to the tertiary level. This, which should not be so in developed economy, was negated by the preference that majority of students in Western Europe prefer public universities to private ones. Varghese (2004) averred that $95 \%$ of students in Western Europe attend public universities and that private universities were well entrenched in East Asia and Latin America.

As Shleifer (1998) clearly shows, private ownership of universities should generally be preferred to public ownership because of incentives to innovate. So also cost reduction is of paramount importance in private enterprises compared to public institutions. The social goals which are apparently lacking in private firms can be addressed by efficient regulation by government agencies.

Many reforms were made in the Nigerian higher education system particularly in the early part of the $21^{\text {st }}$ century. 
These reforms include the liberalization of private university system; resuscitation of National Open University of Nigeria; introduction of Information and Communication Technology (ICT) for teaching, learning and research; Unified Tertiary Matriculation Examination (UTME); Post UTME screening and Teachers Registration Council.

Some of these reforms as observed by Abdulkareem (2010) were implemented without considering their impacts on other units, levels and types of education available. He further stated that the reforms could be more relevant if environmental challenges and opportunities are considered before initiation and implementation.

Preference of private secondary schools over public secondary schools in Nigeria rests mainly on factors like quality of teachers, good facilities, moderate class size, curriculum practices, stability of academic activities and disciplinary concerns on students (Adebayo, 2009). These factors can be applicable to private universities. Oladipo, Adeosun and Oni (2010) posited that rapid growth in the university age population and the public outcry about the deterioration in quality of public education were the remote causes for the increase of private provisions of higher education in Nigeria. The decline in quality education at the tertiary level were also the result of poor state of the economy; weak internal capacity; poor governance; poor research activities; brain drain; political interference and poor funding.

The efficiency theory in education as elucidated by Psacharopoulos (1980) in his work on Higher Education in Developing Countries put forward two different meanings as being used in education. The first, being internal efficiency of an education institution, measures the training given out and how the students are ultimately turned out while the second efficiency, called external efficiency, measures how graduates fit in the social setting after they leave school in comparison with the resources used. He concluded that external efficiency is a stricter test than internal efficiency simply because the latter does not necessarily imply the former, as for example, an institution might be very efficient at turning out graduates, yet its graduates might not be well rewarded in the labor market; thus not passing the external efficiency test.

\section{Research Methodology}

For the purpose of this study, secondary data were used. Relevant materials such as textbooks, Journals, Newspaper and other official documents both in prints and electronics were widely consulted.

\section{Findings and Discussion}

The Nigerian university graduates up to the 1970s had offers of employment waiting for them even before writing their final papers. Private and public establishments had their recruitment exercises taken to the campuses where students are offered one or more jobs. These are the days that the word 'unemployment' did not exist in the lexicon of the Nigerian graduates. But as soon as the oil glut of the early 1980s set in and industries were folding up coupled with emergence of more university graduates due to establishment of additional universities, graduate unemployment in Nigeria surreptitiously crept in. Graduates were then waiting for months before getting any paid employment. The saving grace for many university graduates at this period was the teaching opportunities in the secondary schools due to establishment of more secondary schools but with inadequate availability of trained teachers. When these secondary schools were choked up with more than enough teachers and the industries were closing down, unemployment of university graduates became real in Nigeria. Graduates then wait for one, two or more years before getting any employment.

The curriculum in the first, second and even to an extent third generation universities are tailored to the demand of civil service in ministries and parastatals. The higher ratio of students in arts and humanities to that of other courses was still maintained when the economy was having challenges thereby throwing many university graduates into unemployment market. The unemployment problems being encountered are being addressed by the introduction of compulsory entrepreneurial programmes in most universities especially the private ones. In respect of private universities offering postgraduate programmes, the era of being hired by employers before graduation as it used to happen up to the early 1970s is being resuscitated. Pan Atlantic University, the hitherto Pan African University had most of its graduating students being offered employment from blue chips company and the rest were in employment within three months of passing out (Alos, 2005).

The outstanding performance of the output of private universities in entrepreneurship fields can be corroborated with the superlative performance in the Presidential Special Scholarship Scheme for Innovation and Development (PRESSID). The first class graduates of Covenant University, a private institution, emerged tops for the second time 
running in 2013. Out of 200 first class candidates that were successful and given special scholarships on innovation and development, 19 candidates were from this university. This shows that private universities that put emphasis on entrepreneurship are fully facing the challenges of the period. (National Universities Commission, 2014). This feat was achieved due to the University's programmes being target-driven and the extensive use of ICT in the teaching and learning processes (Okojie, 2014).

The reward for entrepreneurship, as in simple economics, is the making of profits to be shared and the proprietors of private universities are not excluded. The entrepreneurial spirit of proprietors of private universities had made them rarely producing graduates lower than the grade of second class upper. Even some of them vow to produce only $1^{\text {st }}$ class graduates not minding criticisms from the Nigerian larger society.

The question to ask at this junction is that of the intentions or aims of the proprietors of private universities. Is it purely on business or the love of education? Is it a way of boosting the ego of the proprietor or to cater for a particular political class? According to Osundare (2014), hotel business was common during the oil boom and when it was out of fashion, petrol business replaced it. He concluded that as we are now in the era of proliferation of universities, there is no much difference between the graduates of private schools and public schools despite the higher fees being charged by the former.

The National University Commission is the oversight/regulatory organ for the universities. Its functions among others are the laying down of minimum academic standards in order to ensure that quality is maintained within the academic programmes of the Nigerian university system.

Another reason for the proliferation of illegal universities is the rush to earn degrees at a short period. PhD and Master Degrees often take about a year to be completed in some of these private universities. Educational entrepreneur who masquerades as a private university proprietor assumes that by applying to establish a university, possession of a shopping mall or at best a flat or in the alternative a few acres of land hurriedly acquired in a virgin area would be enough to qualify the business as a university. But application for the establishment of a university is the first step out of fourteen steps required by the National University Commission before the green light to operate one is given (Balogun, 2014).

The high cost of private education is worrisome where the highest paid civil servant in the country earns less than N2 million per annum while the lowest paid were under N120,000. With the exchange rate of N172 to the \$, it becomes increasingly difficult for those at that cadre who are regarded as above average to give affordable and qualitative education to their wards when the lowest tuition fees charged by these private universities hangs around N500,000 per session. But all along, the dire inadequate admission into universities had opened the doors of private universities in neighbouring countries. This has replaced the exodus of Nigerians to some remote countries in the 1980s to the end of the $20^{\text {th }}$ century. Some private universities in Ghana have as much as $60 \%$ of their students from Nigeria and it has been estimated that N160b is being carted yearly to that country as tuition fees (Oyedele, 2014).

The overbearing influences of the proprietors are common practices. Appointments are often made without recourse to established norms in universities globally. Fresh professors are sometimes appointed as vice chancellors and the turnover of these chief executives is worrisome. A situation where there are four vice chancellors in a university within a period of three years shows how weak and porous the system can be. (Tribune, 2014)

As admission into universities in Nigeria is like the proverbial camel going through the needle's eye, many students that were not successful in the Unified Tertiary Matriculation Examination (UTME) had succor in the private universities by being offered places on platter of gold. Applicants are often being offered places in some of these universities which were not taken as their institutions of choice when making application through the Joint Admission and Matriculation Board. This type of unsolicited offer of admission identifies uncompromising spirit of entrepreneurship in private universities. It may lead to what is called cash and carry in business parlance. Even some regard these institutions as glorified secondary schools where there is no universe

The ratio of students' population to staff in Nigerian universities is on the higher side compared to developed nations. According to the report of the Federal Government Committee on Needs Assessment of Nigerian Public Universities in 2012, the National Open University of Nigeria has 1:363; University of Abuja has 1:122 while Lagos State University has 1:144. In contrast, Harvard University has 1:4; Massachusetts has 1:9 while Cambridge has 1:3 (Micaiah, 2012). Private universities in Nigeria are not near these.

Private universities are concentrated in the southern part of the country. There are less than 10 private universities in the whole north compared to more than 50 in the south (Suleiman, 2013). Reverse is the case when the number of federal public universities is considered for both regions. 


\section{Summary, Conclusions and Recommendations}

The issue of the desirability of private universities in Nigeria was the focus of this paper in respect of their performances in the education sector. Has the private universities in Nigeria fulfilled the mission for which they are established? Are they established purposely to fill the gaps created by public universities or the needs of the society? The paper then attempts to highlight the strengths and weaknesses of these establishments. The history of formal education in Nigeria was discussed with emphasis on higher education. The roles played by Joint Admission Matriculation Board (JAMB) and the regulatory agency - National Universities Commission (NUC) were discussed.

Private university system has contributed meaningfully to the Nigerian society by reducing the unabsorbed number of applicants to the university education. Emphasis is being laid on job creation by these private universities and their performances in entrepreneurial education are more than that of public institutions. The regularity of academic calendar being truncated at will by the public universities by incessant strikes is being maintained as academic staffs of private universities rarely participate in labour unrest. Irregularity of academic calendar in the university education system has a negative impact to the education sector. This has the effect of neigbouring countries offering alternative education to the Nigerian students. According to conservative estimates, more than N160 billion were repatriated as tuition fees yearly to these neighbouring countries. These institutions in the neighbouring countries were privately owned. If private universities in Nigeria are able to provide the same type or even more qualitative education as these private universities in the neighbouriing countries, a princely capital flight would be avoided.

The National Universities Commission should increase its regulatory and oversight functions on these private institutions. Private universities should not be glorified secondary schools where the whims and caprices of the proprietors override the established norms of universities. The overbearing influences of the owners should be checked. Strict adherence of staffing requirement should be followed. Cross movement of academic and non academic staff carried out by the proprietor without due process should be discouraged. Universities should not be turned to regimented and intellectual prison yards for staff and students. Because of its peculiarity, operations of universities should be left in the hands of professionals for effective management (Okojie, 2008).

The work load of academic staff is often on higher side. A situation where a lecturer takes as much as four or even five courses should in its entirety be discontinued.

The era of employers finding Nigerian graduates unemployable should be addressed by the private universities by giving qualitative and realistic education that is demanded by the labour market. Demand of the society should be the focus of the curriculum being offered. The external efficiency of educational establishments, according to Psacharopoulos (1980), where attention is paid to cost and the kind of output produced should be paramount in any Nigerian private university.

\section{References}

Abdulkareem, A.Y. (2010). Reforms in Higher Education in Nigeria and the Challenges of Globalisation Edited Conference Proceedings of the $1^{\text {st }}$ International Conference on Higher Education and Globalization at University of Ilorin Auditorium Feb 8-10, 2010 https://www.unilorin.edu.ng/.../Reforms_in_higher_education_in_nigeria...

Adebayo, F. A. (2009). Parents' Preference for Private Secondary Schools in Nigeria, Int J Edu Sci, 1(1): 1-6 (2009) www.krepublishers .com/.../JES-01-01-001-09-004-Adebayo-F-A-Tt.pd...

Adeuyan, J. A. (2011) Contributions of Yoruba People in the Economic \& Political Developments of Nigeria Retrieved from http://books.google.com.ng/books?isbn=1467024805 on Tuesday August 26, 2014.

Ajadi, T. O. (2010). Private Universities in Nigeria - the Challenges Ahead, American Journal of Scientific Research ISSN 1450-223X Issue 7 (2010), pp.15-24.

Alos, A. J. (2005) Pan African University Annual Report 2005, Report of the Vice-Chancellor, p2.

Balogun, A. (2014) Unbelievable! University inside shopping mall, The Sun Newspaper, 23, pp2 http://www.punchng.com/ on Friday August 29, 2014.

Joint Admission and Matriculation Board Act Cap 193 Laws of the Federation of Nigeria 2004.

Micaiah, W. (2014) Facts fromCommittee on Needs Assessment of Nigerian Public Universities. Retrieved from http://walemicaiah.blog.com/2012/11/5 on Saturday August 9, 2014.

National Universities Commission Act Cap N81, Laws of the Federation of Nigeria 2004.

Obasi, I.N. (2007). Analysis of the Emergence and Development of Private Universities in Nigeria (1999-2006) Council for the Development of Social Science Research in Africa 2007 (ISSN 0851-7762) JHEA/RESA Vol. 5, Nos. 2\&3, 2007, pp.39-66

Okojie, J. (2008) Licensing, Accreditation and Quality Assurance in Nigerian Universities: Achievements and Challenges Paper presented at a session of the 2008 CHEA Summer Workshop Retrieved from www.chea.org/pdf/2008_SW_Julius_Okojie_ paper.pdf on Saturday July 5, 2014. 
Okojie, J. (2014) Covenant University tops presidential scholarship scheme, Retrieved from http://covenantuniversity.edu.ng/News on Friday 22, 2014.

Oladipo, A., Adeosun, O and Oni, A. (2010). Quality Assurance and Sustainable University Education in Nigeria aadcice.hiroshimau.ac.jp/e/reseach/paper_no9-1.pdf

Osundare, N. (2014), Our universities need to be universal in teaching, learning approach, BusinessDay Newspaper, March 20, p8.

Oyedele, D. (2014) How Ghana Sub-Standard Universities Fleece Nigerian Students, THISDAY Newspaper, March 2, pp2.

Psacharopoulos, G. (1980). Higher Education in Developing Countries: A Cost-Benefit Analysis, World Bank Staff Working Paper No.440, World Bank, Washington, D. C.

Saint, W. (2004) Higher Education in Ethiopia: The Vision and Its Challenges JHEA/RESA Vol. 2, No. 3, 2004, pp.83-113.

Shleifer, A. (1998) States versus Private Ownership, NBER Working Paper Series http://www.nber.org/papers/w6665

Suleiman, S. (2013) Private universities in Nigeria: Where are the 'big' men? - Retrieved from nigerianstalk.org/.../private-universities-innigeria-where-are-the-big-me on Friday August, 27, 2014

Thaver, B. (2008). The Private Higher Education Sector in Africa: Current Trends and Themes in Six Country Studies Council for the Development of Social Science Research in Africa 2008 (ISSN 0851-7762) JHEA/RESA Vol. 6, No. 1, 2008, pp.127-142.

Tribune Newspaper (2014) Private Varsities: A wake up call, Retrieved from http://tribune.com.ng/quicklinks/editorial on Tuesday August 26, 2014.

Uche, A. M. (2012). Neglecting the public and focusing on the private: 'The situation of education in Nigeria' Master Programme in Global Studies University of Gothenburg, School of Global Studies.

Varghese, N.V. (2004) Private Higher Education in Africa. International Institute of Educational Planning. Retrieved from http://www. unesco. org/liep on Sunday January 6, 2013. 